Pebrianti Sarira P dan A.Marzuki, Pemberian Mulsa Jerami dan Pupuk Kascing Pada Rumput Setaria (Setaria sphacelata)

\title{
PEMBERIAN MULSA JERAMI PADI DAN PUPUK KASCING PADA RUMPUT SETARIA (Setaria sphacelata)
}

Oleh :

\section{PEBRIANTI SARIRA PALULUN*) dan ACHMAD MARZUKI**)}

Limbah ternak dan pertanian adalah sisa buangan dari suatu kegiatan usaha peternakan dan pertanian seperti usaha pemeliharaan ternak dan sisa hasil pertanian, bila dibiarkan dapat berdampak buruk bagi lingkungan, manusia dah bahkan ternak itu sendiri. Salah satunya limbah padat seperti feses dan jerami padi. Dari limbah ternak tersebut para peternak juga dapat menghasilkan keuntungan karena limbah tersebut dapat diolah menjadi pupuk organik. Pupuk organik tersebut dapat dimanfaatkan untuk tanaman rumput sehingga para peternak dapat menyajikan hijauan berkualiatas unggul dan ekonomis.

Kascing atau vermicompost adalah kotoran cacing tanah. Kascing mengandung unsur hara yang lengkap, baik unsur makro dan mikro yang berguna bagi pertumbuhan tanaman. Unsur-unsur kimia yang terkandung di dalamnya siap diserap tanaman dan sangat berguna bagi pertumbuhan dan produksinya. Disamping itu kascing mengandung mikroba dan hormon perangsang pertumbuhan tanaman. Jumlah mikroba yang banyak dan aktivitasnya yang tinggi bisa mempercepat pelepasan unsur-unsur hara dari kotoran cacing menjadi bentuk yang tersedia bagi tanaman

Mulsa adalah material penutup tanaman budidaya yang dimaksudkan untuk menjaga kelembaban tanah serta menekan pertumbuhan gulma dan penyakit sehingga membuat tanaman tersebut tumbuh dengan baik. Mulsa dibedakan menjadi dua macam dilihat dari bahan asalnya, yaitu mulsa organik dan anorganik. Salah satu bahan yang dapat digunakan sebagai mulsa organik adalah jerami (Adisarwanto dan Wudianto dalam Mariano. 2003). Mulsa organik jerami padi dapat meningkatkan dan mempertahankan kandungan air tanah lebih dibandingkan mulsa golongan leguminosa karena mulsa jerami padi lebih tahan. (Yoyo dalam Agusni dkk. 2000).

Tujuan peneliti ini adalah untuk mengetahui pengaruh penggunaan mulsa organik jerami padi dan pupuk kascing terhadap pertumbuhan dan produsi rumput Setaria sphacelata.

Penelitian ini menggunakan Rancangan Acak Kelompok (RAK) Non Faktorial dengan empat perlakuan dan lima kali ulangan, adapun perlakuannya adalah P1 yaitu mulsa organik jerami padi : 12 $\mathrm{kg} /$ bedeng, P2 yaitu pupuk kascing : 300 gr/rumpun dan K3 yaitu kombinasi mulsa organik jerami padi : 6 $\mathrm{kg} /$ bedeng dan pupuk kascing : 150gr/rumpun.

Hasil penelitian menunjukkan bahwa respon pertumbuhan dan produksi rumput Setaria sphacelata yang terbaik dihasilkan oleh perlakuan P2, dengan hasil jumlah anakan 84,25, panjang daun 40,08cm, tinggi tanaman $57,38 \mathrm{~cm}$, dan produksi 4,90 $\mathrm{kg}$. Pemupukan dilakukan sebanyak dua kali yaitu pada periode defoliasi yang dilakukan dua minggu setelah penanaman dan pemupukan kedua dilakukan dua hari sebelum panen.

Dari hasil penelitian ini, disimpulkan bahwa pupuk kascing (P2) dengan dosis 300 gr/rumpun dapat meningkatkan pertumbuhan dan produktivitas rumput Setaria sphacelata pada saat defoliasi dan panen. Perlakuan dengan mulsa organic jerami padi dan kombinasi antara mulsa organic jerami padi dan pupuk kascing (P1 dan P3) memiliki tingkat pertumbuhan dan produksi yang kurang baik terhadap rumput Setaria sphacelata yaitu dengan hasil produksi P1 0,36 kg/bedeng dan K3 0,81 kg/bedeng (defoliasi) dan P1 2,60 $\mathrm{kg} /$ bedeng dan 4,40 kg/bedeng (panen).

Untuk tanaman rumput Setaria sphacelata dapat menggunakan pupuk kascing dengan dosis 300 gram/rumpun tanpa harus menggunakan mulsa, karena hanya dengan pemberian pupuk kascing 300 gram/rumpun pertumbuhan dan produksinya tinggi.

Kata kunci : jerami padi, kascing, rumput setaria 


\section{PENDAHULUAN}

\subsection{Latar Belakang}

Kebutuhan akan bahan pangan terus meningkat seiring dengan pertambahan penduduk. Dengan kemajuan teknologi beberapa produksi pertanian masih dapat ditingkatkan melalui upaya intensifikasi pertanian. Upaya intensifikasi akhirakhir ini juga mengalami hambatan seperti semakin kecilnya subsidi pemerintah terhadap sarana produksi pertanian (pupuk, pestisida dll).

Dengan adanya krisis ekonomi yang dialami oleh negara kita sampai sekarang, dampak ini juga dirasakan oleh para petani. Dimana daya beli masyarakat tani menjadi berkurang dan ditambahkan lagi harga pupuk dan sarana produksi lain yang semakin tinggi. Masalah ini menyebabkan petani tidak banyak menerapkan budidaya yang baik untuk meningkatkan produksinya.

Pada umumnya, petani peternak di pedesaan memberi pakan ternaknya berupa rumput yang tumbuh secara alami. Peningkatan produktivitas ternak yang optimal dengan pemberian pakan rumput alami akan sulit dicapai, sebab kualitas pakan tersebut rendah dan jumlahnya bergantung pada musim penghujan. Salah satu usaha untuk meningkatkan kualitas dan kuantitas rumput sebagai hijauan pakan ternak dapat dilakukan dengan mengembangkan Setaria sphacelata.

Setaria sphacelata merupakan salah satu hijauan yang paling digemari oleh ternak ruminansia. Rumput setaria tumbuh tegak, berumpun lebat, tinggi dapat mencapai $2 \mathrm{~m}$, berdaun halus dan lebar berwarna hijau gelap, berbatang lunak dengan warna merah keunguunguan, pangkal batang pipih, dan pelepah daun pada pangkal batang tersusun seperti kipas. Rumput setaria sangat cocok di tanam di tanah yang mempunyai ketinggian $1200 \mathrm{~m} \mathrm{dpl,} \mathrm{dengan}$ curah hujan tahunan $750 \mathrm{~mm}$ atau lebih, dapat tumbuh di berbagai jenis tanah, dan tahan terhadap genangan air.

Dilain pihak produksi yang rendah disebabkan beberapa hal, yaitu banyak petani yang belum menerapkan cara budidaya yang baik, seperti penggunaan pupuk yang kurang berimbang, perawatan yang kurang intensif dan salah perhitungan waktu tanam. Pupuk buatan yang digunakan selama ini dapat menyebabkan rusaknya struktur tanah akibat pemakaian pupuk buatan yang terus menerus sehingga perkembangan akar tanaman menjadi tidak sempurna. Hal ini juga akan memberi dampak terhadap produksi tanaman yang diusahakan pada tanah yang biasa diberikan pupuk buatan. Begitu juga dari efek sarana produksi terhadap lingkungan telah banyak dirasakan oleh masyarakat petani, penggunaan pupuk buatan yang terus menerus menyebabkan ketergantungan dan lahan mereka menjadi lebih sukar untuk diolah.

Pupuk organik mempunyai efek jangka panjang yang baik bagi tanah, yaitu dapat memperbaiki struktur kandungan organik tanah dan selain itu juga menghasilkan produk pertanian yang aman bagi kesehatan. Oleh karena itu sekarang ini penggunaan pupuk organik digalakkan pemakaiannya di kalangan petani.

Kascing (kotoran bekas cacing), yang selama ini dibuang, karena dianggap kotor dan bau ternyata dapat dimanfaatkan menjadi pupuk tanaman. Kascing atau vermicompost adalah kotoran cacing tanah. Kascing mengandung unsur hara yang lengkap, baik unsur makro dan mikro yang berguna bagi pertumbuhan tanaman. Unsurunsur kimia yang terkandung di dalamnya siap diserap tanaman dan sangat berguna bagi pertumbuhan dan produksinya. Disamping itu kascing mengandung mikroba dan hormon perangsang pertumbuhan tanaman. Jumlah mikroba yang banyak dan aktivitasnya yang tinggi bisa mempercepat pelepasan unsur-unsur hara dari kotoran cacing menjadi bentuk yang tersedia bagi tanaman.

Mulsa adalah material penutup tanaman budidaya yang dimaksudkan untuk menjaga kelembaban tanah serta menekan pertumbuhan gulma dan penyakit sehingga membuat tanaman tersebut tumbuh dengan baik. Mulsa dibedakan menjadi dua macam dilihat dari bahan asalnya, yaitu mulsa organik dan anorganik. Mulsa organik berasal dari bahan-bahan alami yang mudah terurai seperti sisa-sisa tanaman seperti jerami dan alang-alang. Mulsa organik diberikan setelah tanaman /bibit ditanam. Keuntungan mulsa organik adalah lebih ekonomis (murah), mudah didapatkan, dan dapat terurai sehingga menambah kandungan bahan organik dalam tanah. Contoh mulsa organik adalah alang - alang/jerami, ataupun cacahan batang dan daun dari tanaman jenis rumput-rumputan lainnya. Mulsa anorganik terbuat dari bahan-bahan sintetis yang sukar/tidak dapat terurai. Contoh mulsa anorganik adalah mulsa plastik, mulsa plastik hitam perak atau karung. Mulsa anorganik ini harganya mahal.

Dalam penelitian ini akan digunakan Mulsa organik jerami padi . Pemanfaatannya dapat secara langsung, yaitu ditutupkan pada permukaan tanah di sekitar tanaman. Tanah yang tidak menggunakan mulsa akan mudah terkena 
Pebrianti Sarira Palulun dan Achmad Marzuki, Pemberian Mulsa Jerami Padi dan Pupuk Kascing Pada Rumput Setaria (Setaria sphacelata)

erosi bila erkena air hujan maupun pecah-pecah apabila terlalu banyak penguapan. Seperti diketahui bahwa erosi akan memperburuk kesuburan tanah dan menghambat pertumbuhan dan perkembangan tanaman serta tanaman menjadi mudah roboh. Sedangkan kondisi tanah yang pecah-pecah pada musim kemarau akan berpengaruh buruk pada perakaran tanaman berupa putusnya akar.

\subsection{Rumusan Masalah}

1. Apakah penggunaan Mulsa organik jerami padi yang dikombinasikan dengan pupuk kascing berpengaruh terhadap pertumbuhan dan produksi rumput setaria?

2. Apakah penggunaan Mulsa organik jerami padi berpengaruh terhadap pertumbuhan dan produksi rumput setaria?

3. Apakah penggunaan pupuk kascing berpengaruh terhadap pertumbuhan dan produksi rumput setaria?

\subsection{Tujuan Penelitian}

Tujuan dari penelitian ini adalah untuk mengetahui pengaruh penggunaan mulsa organik jerami padi dan pupuk kascing terhadap pertumbuhan dan produksi rumput setaria (Setaria sphacelata).

\subsection{Manfaat Penelitian}

Penelitian ini diharapkan dapat memberikan informasi kepada peternak tentang pengaruh penggunaan mulsa jerami padi dan pupuk kascing terhadap pertumbuhan rumput setaria

\subsection{Hipotesis}

Hipotesis dari penelitian ini adalah :

H0: Mulsa organik jerami padi dan pupuk kascing tidak berpengaruh pada pertumbuhan rumput setaria (Setaria sphacelata)

H1: Mulsa organik jerami padi dan pupuk kascing berpengaruh pada pertumbuhan rumput setaria (Setaria sphacelata)

\section{METODOLOGI PENELITIAN}

\subsection{Waktu dan Tempat}

Penelitian ini dilaksanakan pada bulan Juli sampai dengan Oktober 2010 yang bertempat di Lahan Hijauan Makanan Ternak (HMT) Politeknik Negeri Jember.

\subsection{Alat dan Bahan}

Alat yang digunakan adalah buku sebagai tempat mencatat data, cangkul untuk mengolah tanah, timbangan, meteran. Bahan yang digunakan adalah rumput Setaria sphacelata, mulsa organik jerami padi, pupuk kascing dan kotoran sapi.

\subsection{Rancangan Penelitian}

Penelitian ini menggunakan Rancangan Acak Kelompok (RAK) Non Faktorial dengan empat perlakuan dan lima kali ulangan. Adapun perlakuannya adalah:

$\mathrm{P} 0=$ Kontrol (tanpa penggunaan mulsa organik jerami padi dan pupuk kascing).

$\mathrm{P} 1=$ Penggunaan mulsa organik jerami padi 12 $\mathrm{kg} / \mathrm{bedeng}$

$\mathrm{P} 2=$ Penggunaan pupuk kascing 300g/rumpun

P3= Penggunaan mulsa organik jerami padi dan pupuk kascing (6 kg mulsa jerami padi dan $150 \mathrm{~g}$ pupuk kascing)

\subsection{Variabel Penelitian}

1. Variabel Bebas

Variabel bebas dari penelitian ini adalah kascing dan Mulsa, dosis pupuk, dan jarak tanam.

2. Variabel Terikat

Variabel terikat dari penelitian ini adalah pertumbuhan dan produktivitas rumput setaria (jumlah anakan, panjang daun, tinggi tanaman dan produksi tanaman).

\subsection{Prosedur Pelaksanaan}

1. Pengolahan tanah/lahan seluas $20,5 \mathrm{~m} \times$ $7,5 \mathrm{~m}$

2. Pembuatan bedengan 300 x $150 \mathrm{~cm}$ (panjang : $300 \mathrm{~cm}$ dan lebar : $150 \mathrm{~cm}$ ) dengan jarak antar bedengan adalah 50 $\mathrm{cm}$.

3. Pemupukan dasar dengan menggunakan kotoran sapi sebanyak $3 \mathrm{Kg} /$ bedeng (metode ini bertujuan untuk menghomogenkan tanah dan menggemburkan tekstur tanah), dilakukan satu minggu sebelum penanaman rumput

4. Menyiapkan pols rumput setaria sphacelata, pols yang baik diperoleh dari sobekan rumpun yang sehat dan mengandung banyak akar dan calon anakan baru. Bagian vegetatifnya harus dipotong sebelum ditanam, tujuannya adalah agar tanaman baru ini tidak terlampau banyak penguapan dan sebelum system perakaran bisa aktif mengisap air. 
5. Penanaman rumput setaria, dilakukan setelah 1 minggu lahan diberi pupuk dasar dengan jarak tanam $50 \times 50 \mathrm{~cm}$ yang terdiri atas 10 rumpun dalam 1 bedengan.

6. Setelah penanaman selesai mulsa jerami disebar secara merata di atas permukaan bedengan.

7. Pemupukan rumput setaria, dilakukan 2 minggu setelah penanaman dengan menggunakan pupuk organik kascing (kotoran bekas cacing), guna memacu pertumbuhan rumput Setaria sphacelata. (Bazuki, 2004)

8. Penyiangan (membersihkan gulma dari tanaman)

\section{Jumlah anakan}

Pengamatan jumlah anakan rumput setaria yaitu dengan cara mengamati rumput setaria yang baru tumbuh di sekitar indukan lihat pada gambar 3.1. setiap perlakuan diambil $20 \%$

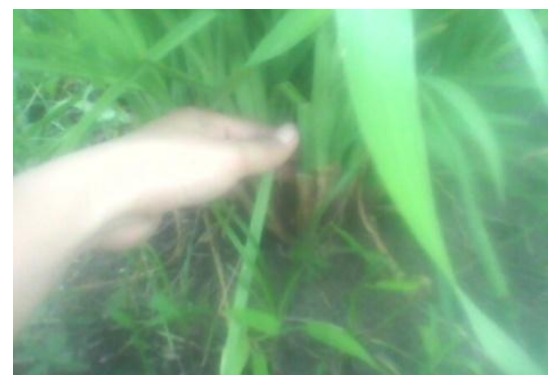

9. Pemberian pupuk kembali dilakukan 2 hari sebelum defoliasi dengan menggunakan pupuk kascing, guna memacu pertumbuhan rumput Setaria sphacelata berikutnya.

10. Setelah \pm 40 hari dilakukan defoliasi/potong paksa pada tanaman rumput setaria

11. Setelah rumput berumur \pm 30 hari dilakukan pemanenan.

\subsection{Parameter Pengamatan}

Pengamatan pada tanaman rumput setaria dilakukan 1 minggu sekali setelah dilakukan defoliasi atau pemotongan paksa sampai panen. Parameter yang diamati adalah :

dari populasi sehingga dari setiap bedeng atau perlakuan diambil 2 sampel secara acak. Metode dalam menetukan jumlah anakan pada pertumbuhan tanaman rumput setaria

Gambar 3.1. Anakan yang tumbuh pada tanaman setaria sphacelata

\section{Panjang daun}

Pengukuran panjang daun rumput setaria mulai dari pangkal daun pada batang sampai dengan ujung daun lihat pada gambar 3.2. setiap perlakuan diambil $20 \%$ dari populasi sehingga dari setiap bedeng atau perlakuan diambil 4 sampel secara acak. Panjang daun yang diukur dari satu rumpun rumput setaria diambil 3 sampel panjang daun kemudian diambil rata-rata. Metode pengukuran panjang daun pada pertumbuhan rumput setaria 
Pebrianti Sarira Palulun dan Achmad Marzuki, Pemberian Mulsa Jerami Padi dan Pupuk Kascing Pada Rumput Setaria (Setaria sphacelata)

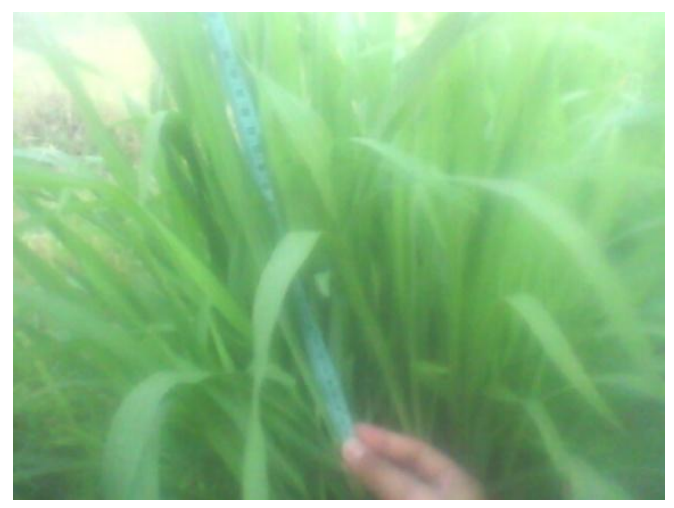

Gambar 3.2 Cara Pengukuran Panjang Daun

3. Tinggi tanaman

Pengukuran tinggi rumput setaria mulai dari dasar tanah sampai dengan ujung daun yang paling tinggi lihat pada gambar 3.3. Dari setiap perlakuan diambil $20 \%$ dari populasi sehingga dari setiap bedeng atau perlakuan diambil 4 sampel secara. Metode pengukuran tinggi tanaman〉

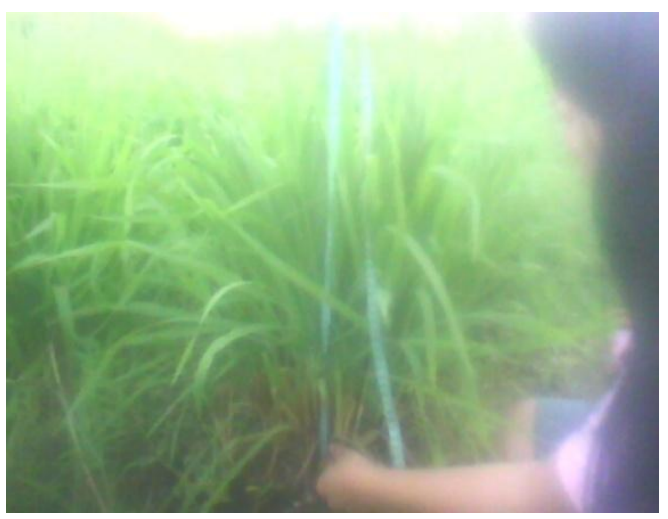

Gambar 3.3 cara pengukuran tinggi tanaman

4. Produksi tanaman rumput setaria

Pada saat umur rumput setari 40 hari dilakukan pemanenan, hasil panen per bedeng/perlakuan ditimbang kemudian dirata- ratakan untuk menentukan banyaknya produksi rumput setaria untuk setiap perlakuan dan untuk panen kedua dilakukan saat rumput berumur 30 hari. 


\section{HASIL DAN PEMBAHASAN}

\subsection{Jumlah Anakan Rumput}

Berdasarkan hasil analisis ragam ditunjukkan bahwa penggunaan pupuk kascing dan mulsa berpengaruh nyata $(\mathrm{P}<0,05) \quad$ terhadap pertumbuhan jumlah anakan pada minggu pertama, minggu ketiga, dan minggu keempat.
Sedangkan pada minggu kedua menunjukkan pengaruh yang tidak nyata terhadap pertumbuhan jumlah anakan.

Rata-rata pertumbuhan jumlah anakan rumput Setaria sphacelata dapat dilihat pada Tabel 4.1 sedangkan Grafik rata-rata pertumbuhan jumlah anakan disajikan pada Gambar 4.1

Tabel 4.1 Rata-rata Pertumbuhan Jumlah Anakan Rumput Setaria sphacelata

\begin{tabular}{lllcl}
\hline \multirow{2}{*}{ Perlakuan } & \multicolumn{3}{c}{ Rata-rata Jumlah Anakan } \\
& Minggu 1 & Minggu 2 & Minggu 3 & Minggu 4 \\
\hline P0 & $23,10^{\mathrm{ab}}$ & $26,40^{\mathrm{a}}$ & $33,90^{\mathrm{b}}$ & $41,38^{\mathrm{b}}$ \\
P1 & $15,60^{\mathrm{b}}$ & $16,10^{\mathrm{a}}$ & $27,80^{\mathrm{bc}}$ & $34,88^{\mathrm{bc}}$ \\
P2 & $37,60^{\mathrm{a}}$ & $63,60^{\mathrm{a}}$ & $58,96^{\mathrm{a}}$ & $84,25^{\mathrm{a}}$ \\
P3 & $30,90^{\mathrm{a}}$ & $42,50^{\mathrm{a}}$ & $50,40^{\mathrm{a}}$ & $69,38^{\mathrm{a}}$ \\
\hline
\end{tabular}

Keterangan: Angka yang diikuti oleh huruf yang sama menunjukkan tidak berbeda nyata pada uji BNT 5\%

Hasil uji lanjut BNT taraf 5\% dengan parameter jumlah anakan minggu pertama setelah diuji lanjut P1 memiliki pengaruh yang berbeda nyata terhadap P2 dan P3 dan juga berbeda nyata terhadap P0. Sedangkan kedua perlakuan P2 dan P3 juga berbeda nyata terhadap P0. Kemudian pada pengamatan jumlah anakan minggu kedua menunjukkan tidak ada pengaruh yang berbeda nyata pada masing-masing perlakuan atau non significan (ns). Pada minggu ketiga dan keempat pengamatan $\mathrm{P} 0$ memiliki pengaruh yang berbeda nyata terhadap P2 dan P3 dan juga berbeda nyata terhadap P1.

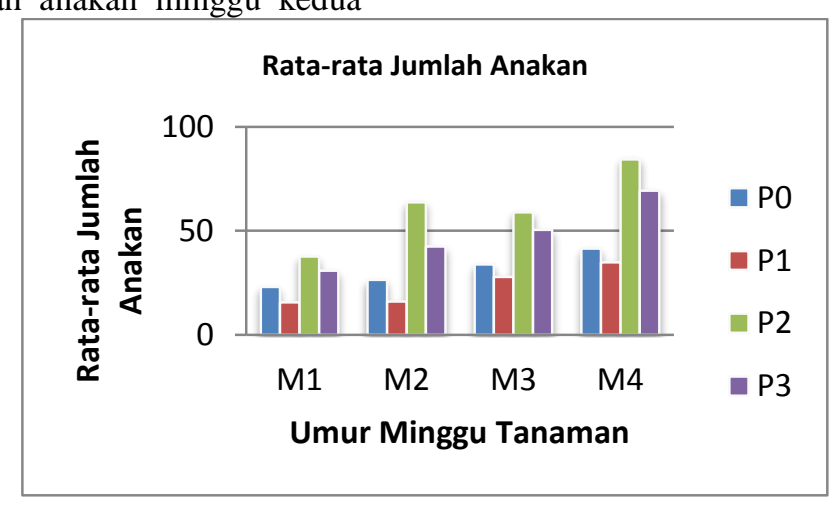

Gambar 4.1 Grafik Jumlah Anakan

Berdasarkan Gambar diatas terlihat bahwa P2 memiliki tingkat pertumbuhan jumlah anakan yang lebih tinggi dibandingkan P0, P1, dan P3. Dan tingkat pertumbuhan terendah terlihat pada perlakuan P1. Diduga perlakuan dengan pupuk kascing pada P2 lebih berpengaruh nyata dibandingkan perlakuan dengan menggunakan mulsa saja pada P1 karena pupuk kascing mengandung mikroba dan hormon perangsang pertumbuhan tanaman (Tomatti dkk dalam Nurmawanti dkk (2000). Selain itu, pupuk kascing mengandung unsur $\mathrm{N}$ yang berfungsi memacu pertumbuhan tanaman secara umum, terutama pada fase vegetatif, Berperan dalam pembentukan klorofil, asam amino, lemak, enzim, dan persenyawaan lain (Anonim, 2006). 
Pebrianti Sarira Palulun dan Achmad Marzuki, Pemberian Mulsa Jerami Padi dan Pupuk Kascing Pada Rumput Setaria (Setaria sphacelata)

Sementara perlakuan dengan menggunakan mulsa saja kurang memacu pertumbuhan tanaman karena peran mulsa lebih kepada kesuburan tanah bukan pada tanaman secara langsung, seperti yang dinyatakan oleh Thomas et al, (1993) bahwa fungsi mulsa jerami adalah untuk menekan pertumbuhan gulma, mempertahankan agregat tanah dari hantaman air hujan, memperkecil erosi permukaan tanah, mencegah penguapan air, dan melindungi tanah dari terpaan sinar matahari. Juga dapat membantu memperbaiki sifat fisik tanah terutama struktur tanah sehingga memperbaiki stabilitas agregat tanah.

\subsection{Panjang Daun Rumput}

Berdasarkan hasil analisis ragam ditunjukkan bahwa penggunaan pupuk kascing dan mulsa tidak berpengaruh nyata $(\mathrm{P}>0,05)$ terhadap pertumbuhan panjang daun pada minggu pertama, minggu kedua, minggu ketiga, dan minggu keempat.

Rata-rata pertumbuhan panjang daun rumput Setaria sphacelata dapat dilihat pada Tabel 4.2 sedangkan Grafik rata-rata pertumbuhan panjang daun disajikan pada Gambar 4.2

Tabel 4.2 Rata-rata Pertumbuhan Panjang Daun Rumput Setaria sphacelata

\begin{tabular}{lllll}
\hline \multirow{2}{*}{ Perlakuan } & \multicolumn{2}{l}{ Rata-rata Panjang Daun } & & \\
& Minggu 1 & Minggu 2 & Minggu 3 & Minggu 4 \\
\hline P0 & 29,64 & 37,02 & 36,68 & 40,82 \\
P1 & 25,02 & 32,72 & 29,22 & 34,72 \\
P2 & 26,84 & 39,00 & 39,52 & 40,08 \\
P3 & 27,30 & 42,12 & 36,16 & 35,84 \\
\hline
\end{tabular}

Dari hasil pengamatan panjang daun yang ditampilkan pada Tabel diatas pada minggu pertama, kedua, ketiga dan keempat menunjukkan tidak ada pengaruh yang berbeda nyata pada masing-masing perlakuan. Hal ini dimungkinkan karena telah dilakukan defoliasi sebelum pengamatan, Tujuan defoliasi adalah adalah untuk menstimulir pertumbuhan dan untuk memperbanyak anakan serta menyeragamkan pertumbuhan berikutnya (suwarsono, 2009), sehingga tidak terlihat perbedaan yang nyata untuk masing-masing perlakuan pada pertumbuhan panjang daun setiap minggunya.

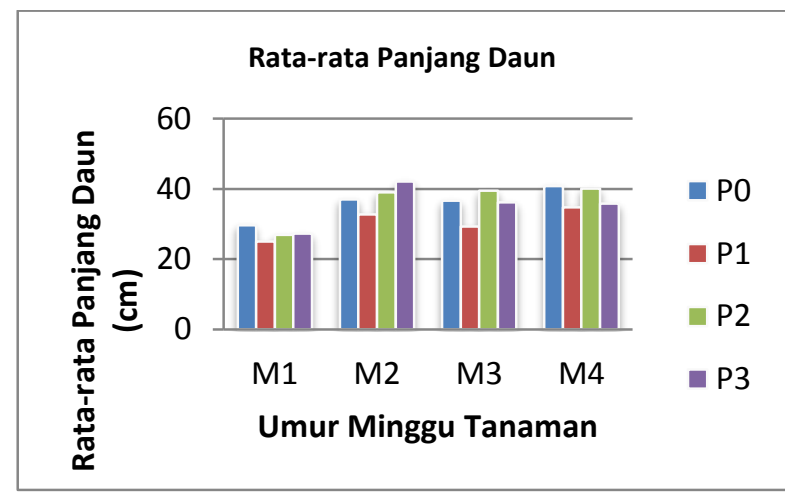

Gambar 4.2 Grafik Panjang Daun

Pada pengamatan minggu pertama dan minggu keempat P0 memiliki tingkat pertumbuhan yang lebih tinggi dibandingkan P1, P2, dan P3 dan pada pengamatan minggu kedua $\mathrm{P} 3$ lebih unggul dibandingkan dengan $\mathrm{P} 0, \mathrm{P} 1$, dan $\mathrm{P} 2$, kemudian minggu ketiga P2 lebih unggul dibandingkan P0, P1 dan P3. Hal ini juga disebabkan karena unsur hara yang terkandung pada pupuk kascing terutama $\mathrm{N}$ yang berfungsi mempercepat pertumbuhan tanaman (Anonim, 2006). 


\subsection{Tinggi Tanaman Rumput}

Berdasarkan hasil analisis ragam ditunjukkan bahwa penggunaan pupuk kascing dan mulsa berpengaruh nyata $(\mathrm{P}<0,05) \quad$ terhadap pertumbuhan tinggi tanaman rumput pada minggu pertama, minggu kedua, dan minggu keempat.
Sedangkan pada minggu ketiga menunjukkan pengaruh yang tidak nyata terhadap pertumbuhan tinggi tanaman rumput.

Rata-rata pertumbuhan tinggi tanaman rumput Setaria sphacelata dapat dilihat pada Tabel 4.3 sedangkan Grafik rata-rata pertumbuhan tinggi tanaman di sajikan pada Gambar 4.3

\section{Tabel 4.3 Rata-rata Pertumbuhan Tinggi Tanaman Rumput Setaria sphacelata}

\begin{tabular}{lllll}
\hline \multirow{2}{*}{ Perlakuan } & \multicolumn{4}{c}{ Rata-rata Tinggi Tanaman } \\
& Minggu 1 & Minggu 2 & Minggu 3 & Minggu 4 \\
\hline P0 & $37,40^{\mathrm{bc}}$ & $47,58^{\mathrm{a}}$ & $49,48^{\mathrm{a}}$ & $56,60^{\mathrm{a}}$ \\
P1 & $31,86^{\mathrm{c}}$ & $36,52^{\mathrm{b}}$ & $41,46^{\mathrm{a}}$ & $45,88^{\mathrm{b}}$ \\
P2 & $57,38^{\mathrm{a}}$ & $45,48^{\mathrm{ab}}$ & $52,26^{\mathrm{a}}$ & $57,38^{\mathrm{a}}$ \\
P3 & $48,68^{\mathrm{a}}$ & $54,02^{\mathrm{a}}$ & $48,74^{\mathrm{a}}$ & $48,68^{\mathrm{b}}$ \\
\hline
\end{tabular}

Keterangan: Angka yang diikuti oleh huruf yang sama menunjukkan tidak berbeda nyata pada uji BNT 5\%

Hasil uji lanjut BNT taraf 5\% pengamatan tinggi tanaman untuk minggu pertama menunjukkan P1 memiliki pengaruh yang berbeda nyata terhadap P2 dan P3 dan juga berbeda nyata terhadap P0.dan pada kedua perlakuan P2 dan P3 juga menunjukkan pengaruh yang berbeda nyata terhadap P0. Minggu kedua pengamatan terlihat P1 memiliki pengaruh yang berbeda nyata terhadap P0 dan P3 dan juga berbeda nyata terhadap P2, dan pada perlakuan P0 dan P3 juga menunjukkan pengaruh yang berbeda nyata terhadap P2. Pada pengamatan minggu ketiga menunjukkan tidak ada pengaruh yang berbeda nyata pada masing-masing perlakuan. Pengamatan minggu keempat P1 dan P3 berbeda nyata terhadap P0 dan P2

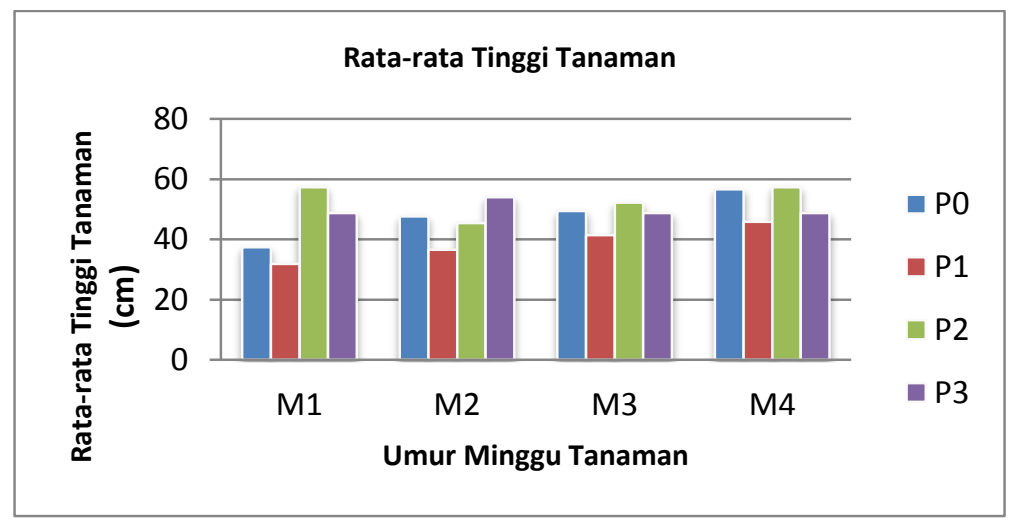

Gambar 4.3 Grafik Tinggi Tanaman

Pada pengamatan minggu pertama sampai keempat P2 memiliki tingkat pertumbuhan tinggi tanaman yang baik, namun pada pengamatan minggu kedua P3 cenderung lebih tinggi dibandingkan $\mathrm{P} 0, \mathrm{P} 1$, dan $\mathrm{P} 2$. Pertumbuhan tinggi tanaman yang paling baik secara keseluruhan terlihat pada P2 dan terendah pada P1. Diduga perlakuan dengan menggunakan pupuk kascing lebih memacu pertumbuhan tanaman dengan unsur hara yang terkandung di dalamnya dari pada hanya menggunakan mulsa saja yang pengaruhnya lebih kepada kesuburan tanahnya saja.

\subsection{Jumlah Produksi Rumput}

Berdasarkan hasil analisis ragam ditunjukkan bahwa penggunaan pupuk kascing dan mulsa berpengaruh nyata $(\mathrm{P}<0,05)$ terhadap jumlah produksi rumput pada saat defoliasi. Sedangkan pada saat pemanenan menunjukkan pengaruh yang tidak nyata terhadap jumlah produksi rumput. 
Pebrianti Sarira Palulun dan Achmad Marzuki, Pemberian Mulsa Jerami Padi dan Pupuk Kascing Pada Rumput Setaria (Setaria sphacelata)

Rata-rata jumlah produksi rumput Setaria sphacelata dapat dilihat pada Tabel 4.4 sedangkan
Grafik rata-rata jumlah produksi disajikan pada Gambar 4.4

Tabel 4.4 Rata-rata Produksi Rumput

\begin{tabular}{|lll|}
\hline Perlakuan & Rata-rata Produksi Tanaman \\
& Defoliasi & Panen \\
\hline P0 & $0,51^{\mathrm{bc}}$ & $2,50^{\mathrm{a}}$ \\
P1 & $0,36^{\mathrm{c}}$ & $2,60^{\mathrm{a}}$ \\
P2 & $0,92^{\mathrm{a}}$ & $4,90^{\mathrm{a}}$ \\
P3 & $0,81^{\mathrm{a}}$ & $4,40^{\mathrm{a}}$ \\
\hline
\end{tabular}

Keterangan: Angka yang diikuti oleh huruf yang sama menunjukkan tidak berbeda nyata pada uji BNT 5\%

Berdasarkan hasil uji BNT 5\% jumlah produksi pada pemotongan paksa (defoliasi) menunjukkan P1 berbeda nyata terhadap P2 dan P3 dan juga berbeda nyata terhadap P0. Dan pada perlakuan P2 dan P3 juga menunjukkan pengaruh yang berbeda nyata terhadap P0. Kemudian jumlah produksi pada hasil panen menunjukkan tidak ada pengaruh yang berbeda nyata pada masing-masing perlakuan atau non significant $(n s)$. Hal ini dimungkinkan karena telah dilakukan defoliasi (pemotongan paksa) sebelum panen. Defoliasi bertujuan menyeragamkan pertumbuhan tanaman sehingga diduga pada saat panen tidak menunjukkan perbedaan yang nyata pada masingmasing perlakuan.

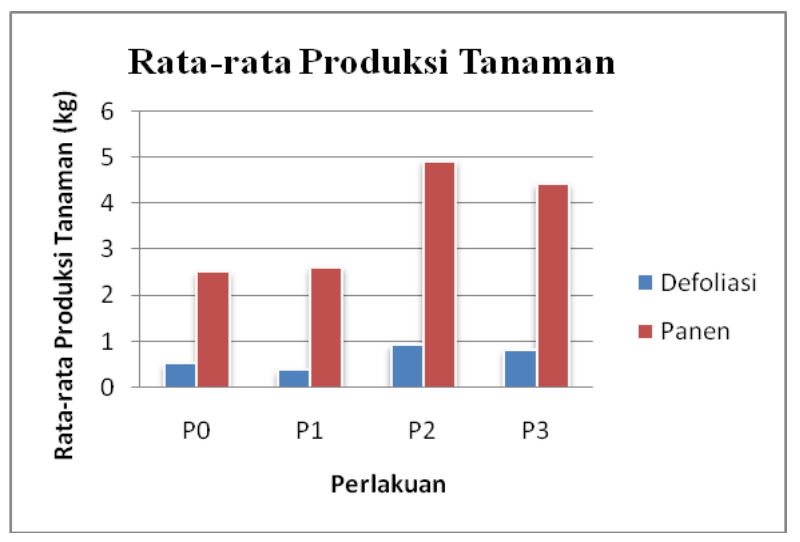

Gambar 4.4 Grafik Produksi Rumput

Pada Grafik terlihat jumlah produksi secara keseluruhan pada saat defoliasi sangat rendah dibandingkan pada saat panen. Namun perlakuan P2 cenderung lebih tinggi dibandingkan P0, P1 dan P3 baik itu pada saat defoliasi maupun panen.

\section{KESIMPULAN DAN SARAN}

\subsection{Kesimpulan}

Berdasarkan hasil penelitian, dapat disimpulkan

1. Perlakuan dengan menggunakan pupuk kascing saja (P2) lebih baik dibandingkan dengan kombinasi antara pupuk kascing dan mulsa jerami padi (P3). Penggunaan pupuk kascing pada P2 dengan dosis $300 \mathrm{gr} / \mathrm{rumpun}$ menghasilkan jumlah anakan 84,25 , panjang daun $40,08 \mathrm{~cm}$, tinggi tanaman $57,38 \mathrm{~cm}$, dan produksi $4,90 \mathrm{~kg}$.

2. Penggunaan pupuk kascing yang dikombinasikan dengan mulsa jerami padi (150gr kascing/rumpun dan $6 \mathrm{~kg}$ mulsa jerami padi/bedeng) menghasilkan pertumbuhan dan produksi kedua tertinggi dari perlakuan-perlakuan lainnya, 
3. Perlakuan dengan menggunakan mulsa saja (P1) memiliki pengaruh yang kurang baik terhadap pertumbuhan dan produksi rumput setaria sphacelata.

5.2 Saran

1. Dalam penanaman rumput setaria sebaiknya menggunakan pupuk kascing saja tanpa mengkombinasikannya dengan mulsa.

2. Dalam penanaman rumput setaria sphacelata menggunakan mulsa jerami padi sebaiknya menggunakan mulsa yang agak basah/lembab jangan yang masih kering karena mulsa yang basah pada waktu mengurai akan memperlancar kegiatan jasad renik tanah sehingga membantu menyuburkan tanah dan sumber humus.

\section{DAFTAR PUSTAKA}

AAK, 1983. Hijauan Makanan Ternak. Kanisius; Jogjakarta.

Agusni, A. Zubair, WS. Ardjasa. 2000. Pengaruh Pupuk Mikroba, Pengolahan Tanah dan Mulsa Terhadap Tanaman Kedelai. Jurnal Penelitian Pertanian Terapan. 7: 20 - 26.

Agus, F. 2002.” Morfologi Rumput Setaria sphacelata". http://www.sith.itb.ac.id/ herbarium/index. Diakses tangga 15 Desember 2009.

Djuarnani, N., Kristiani, dan B.S Setiawan. 2005. Cara Cepat Membuat Kompos. Agromedia Pustaka, Jakarta.

Hanafiah, K.A. 2008. Rancangan Percobaan Teori dan Aplikasi. Raja Grafindo Persada. : Jakarta.
Karo-karo, J. 2007. "Pupuk Kandang". http://www.pustaka.com. Diakses tanggal 18 November 2009.

Mujiyono, SP. 2008. Penanganan Limbah. Bidang peminatan Agribisnis Ruminansia. Modul PJJ.

Nurmawati S., A. Suhardianto. 2000. "Studi Perbandingan Penggunaan Pupuk Kotoran Sapi dengan Pupuk Kascing Terhadap Produksi Tanaman Selada (Lactuca Var Crispa)". http//pupuk kotorannurmawati//0809//.URL.

Sutanto, R. 2005. Penerapan Pertanian Organik. Penebar Swadaya, Jakarta.

Suwasono, J. 2009. "Defoliasi". http://infonak.blogspot.com/2009/04/defoliasi . html

Tanpa nama, 2009. "Pupuk Kandang". www.suarakarya.online.com

2009. "Macam-macam Bahan Organik". http://digilib.mila.ac.id

.2006. "Jenis-jenis dan Kegunaan Unsur Hara".

Widhijanto W, B. 2004. Pengaruh Waktu Pemupukan dan Tekstur Tanah Terhadap Produktivitas Rumput Setaria Splendida Stapf. Majalah ilmiah peternakan. 2 : $60-63$.

Yuwono, D. 2006. Kompos. Jakarta: Penebar Swadaya. 